\title{
IDENTIFYING IDEOLOGY THROUGH COMPARATIVE ANALYSIS OF PAKISTANI \& INDIAN NEWSPAPER HEADLINES
}

\author{
Assistant Professor Dr Shema Bukhari ${ }^{1}$ \\ Girne American University, Communication Faculty, \\ Journalism \& Broadcasting, \\ North Cyprus \\ Assistant Professor Dr Yosra Jarrar ${ }^{2}$ \\ Girne American University, Communication Faculty, \\ Journalism \& Broadcasting, \\ North Cyprus
}

\begin{abstract}
Every country has their own political and military blueprint, followed by all the concerned parties to mould the sympathies of masses based on their agendas. This study aims to evaluate the reporting of major events in Pakistan and India in 2015 that carry implicit/explicit implications; in the newsapapers. Both countries have a history of political, social \& military conflicts, and a struggle against terrorism at various levels. All these difference are presented in different shades in the media discourse based on the discursiveness of the readers. This technique is used to establish and maintain certain ideology; to develop power relations among and between social groups. To explore the underlying interpretation of media discourse, a corpus of headlines is collected from The Dawn, The News from Pakistan and The Times of India, The Hindu from India. Multi-modal Critical Discourse Analysis has helped in examining the headlines at textual and cognitive levels. The comparative analysis revealed that both sides adhere to their nationalistic and political ideology. The Indian media use very strong and emotive rhetoric which helps them in maintaining power relations. Semantic and visual analysis revealed the same ideology in operation, showing the diversity in media communication.
\end{abstract}

Keywords: Comparative Analysis, Headlines, Qualitative, Newspapers, Ideologies.

\section{Introduction}

The news media has undergone major changes over the decades; especially in their approach to news reporting, news writing and various journalistic approaches, owing to the advancement in the digital communication. As the primary objective of news media, especially print media is to give information; therefore, a specified language has been adopted by journalists to convey and simplify the message for the audience. Therefore, concepts of freedom of press, media's role as watch-dogs, objective presentation of news, ideology, free news, autonomous power of media - all come under severe scrutiny and questioning by scholars and audience.

\footnotetext{
${ }^{1}$ Shemabokhari44@gmail.com

2 yosrajarrar@gau.edu.tr
} 
This study investigates the media discourse in newspaper headlines which is dominantly contradictory to 'objectivity'. Ideology and hegemony in the form of power relations will be identified in the headlines of newspapers.

The same media discourse is also responsible for the construction of power relations through the specialized use of language, entertainment formats, positioning of images and extensively pervasive communication. All these concepts are used by journalists to develop a certain agenda, keeping in mind that the news sources are dependent on the conflicts and issues, which serves the purpose of promoting a certain cause, a system of values or a vision. (Rogers \& Dearing, 1996:25)

To understand and evaluate the functioning of these concepts in news discourse; Multimodal Critical Discourse Analysis (MCDA) is employed as the primary method to analyze the discursive nature of text', its 'intersexuality and re-contextualization.' (Wodak, 2001:11)

The current study is an attempt to make sense and provide insight into the underlying meaning of headlines of chosen English newspapers of Pakistan and India because headlines are considered as an individual genre in modern critical studies and deserve our special attention.

This study is unique as it attempts to present a more comprehensive view of the nature of conflict between two rivals.

\section{Historical Perspective:}

Pakistan and India provide a very intriguing case study. Both the countries share thousands of years old history as they were part of a sub-continent before getting separated in 1947, on the ideological grounds based on religion, culture and social aspects. Being a larger state, India had the edge both in economy and finances, right from the beginning, whereas Pakistan had to struggle to bring many factors and factions together. Both the countries fought a war in 1948, for the state of Kashmir, which is still a bone of contention and had been divided into Pakistani and Indian Kashmir. Kashmir region is important for both the nations as the major water sources come from there. The 'waters' of Pakistan come from Indian Kashmir which has subsequently lead to many treaties and conflicts. Consequently, Kashmir region in India is called 'Indian occupied Kashmir' by Pakistan and vice versa. Political front is another major aspect where politicians have been using the Kashmir conflict and hatred-for-each-other card to win elections for decades.

The military front has been very active in the form of four major wars, that is, in 1948, 1965, 1971 (which divided Pakistan into two countries: Pakistan and Bangladesh) and 1999; plus the cross border firing which has become a regular feature. Concurrently, role of military on both sides is much more deep and complicated than the wars fought. Military bureaucracy on both sides survive on greater tension between both sides that guarantees a bigger military budget, hence, greater influence in all matters on national and international interest. The permanent presence of United Nations on both sides to keep a check on the military conflict; is another highlight of the tensions between the two. Another aspect of conflict is based on media, specifically movies and sports.

Taking into account the rivalry between Pakistan and India, this study conducts a comparative analysis of newspaper headlines to analyze and evaluate both the country's newspapers present the same news differently based on their respective ideology to establish a specific agenda. 


\section{Literature Review}

The journalists rely heavily on the 'discursive practices' of the readers to report and write the news. Such practices are based on the already existing culturally embedded cognitive connotations. The readers also read and interpret the news based on the available discourses. Harcup (2002:103) argued that journalists are caught between a perpetual conflict of professional adherence to ethics and unbiased reporting; while at the same time, they have to fulfill the demands of their employers (the media owners) and follow the laid out ideologies. To fulfill these demands; the headlines end up reflecting the practices and views of those who have controlling power to influence the outcome of certain events, which is sadly a normal practice in a capitalistic society.

The ideological differences in the headlines are explained in a study done by al-Ali (2011). He employed van Dijk's socio-ideological discourse theory and Wodak's Historical Approach to analyze the coverage of death of Saddam Hussain. A clear evidence of division is shown between those Arabs who are against the US influence in the region and those who are allied with Washington. Local meanings and lexicalization of Arab newspapers evidently support Saddam Hussein and support his defiance towards America. Main participation's descriptions in all the samples are generally in line and accordance with the socio-political ideology of newspapers. The words and rhetorical styles of the text are reflective of religious ideological bent. All the five newspapers under discussion, presented the event coated in their respective ideological perceptions.

Dave Ferman (2013) successfully presented another aspect of ideology in the headlines in a different scenario. He analyzed the news reporting of the Irish Parade and established two ideologically different newspapers frame. Catholic/nationalist Irish news and the Protestant/Loyalist News Letter framed the 2011 season of religious parade. Although the news was of the same event, place and people but there were significant differences in the presentation of the text through the presentation of double-meanings in themes and meanings. The papers clearly do not pay attention to the cognitive element or the perception of the audience.

Media constitute and enforce ideology. Cheryl Cooky and et al (2013) analysed this phenomenon by doing research on the news coverage of the victory of Caster Semenya (South African athlete) in IAAF 2009 World Championships and later questioning her gender through gender-verification-testing. Amazingly, the media from both sides supported their ideologies by framing the event with the evidence from the respective perspectives.

Van Dijk in his book, 'Ideology: A Multidisciplinary Approach', had systematically explained the attitude, knowledge, behavior, beliefs and cognition of society to establish the fact that the functions of ideology are multi-disciplinary. Ideological discourse just does not depend on any one given factor. While analyzing a media discourse it is pre requisite to keep all the above mentioned factors in mind. He further argued that ideologies function as link between the individualistic and shared properties of social groups. Ideologies are also important to develop and maintain relations in social groups, thus determining and evaluating the conflicting elements in and out of group.

Rotimi Taiwo (2007) conducted a research on 300 Nigerian newspaper headlines to analyze how headlines are used to sustain and maintain power relations to develop ideologies. Large percentage of headlines was political based, with a prominent focus on crime and corruption. Speech headlines were employed by many papers to idealize the social participants. Some headlines were 
being blunt enough to adopt the tome of confrontation. These headlines are used to establish power relations and ideology among its readers.

\section{Method}

The study of media discourse is no longer linguistic or empirical research. It has become more interpretative, contextual, with meanings lurking under-the-surface and ideologies. The research patterns on print media reveal interesting results, which has left us with some questions. For example:

- What effect media has on the society?

- How can we determine the association and causation of these effects?

Critical Discourse Analysis (CDA) is not just a single, independent theory; rather it is an interdisciplinary system of research with multi-layered approaches of various theories and methods (Wodak, 1999:189). The major contributors and developers of CDA include van Dijk, Fairclough and Wodak. Therefore, this dissertation is mainly based on the three major approaches of CDA, namely: Fairclough's Critical approach, Wodak's Discourse - Historical Approach and van Dijk's Sociocognitive Approach. But MCDA goes a step further. According to Emilia Djonov and Sumin Zhao (2014:3), MCDA has sought and followed two inter-dependent directions. First direction deals with tracing the historical background that constitutes the semiotic resources at local level and the second direction focuses on analyzing the relation and interaction between varied semiotic resources in their social context. So, MCDA is a relatively new extension of interdisciplinary CDA but it is considered as one of the "most influential and visible branches of discourse analysis." (Blommaert \& Bulcaen, 2000). It strongly hinged on the strong theories of CDA. Very conveniently it covers the theory to unlock systematic communication, theoretical beliefs about the connection between discourse and power, theory about the social contexts of things and events; to name the few. Since the media discourse does not occur in a vacuum, therefore, MCDA, attempts to cover and analyze all the mediums, channels and aspects that are concerned with a specific discourse.

In this study, MCDA is used as a method and approach to analyze the media discourse in the form of headlines at many levels. There is a detailed textual analysis related to the social context and interpretation of visual features.

\section{Research Design}

The Headlines and their Leads are collected from four major English newspapers of Pakistan and India. "The Dawn" and "The News" from Pakistan and "The Times of India" and "The Hindu" from India of the year 2015. These papers are chosen for their wide popularity, credibility and readership among the masses, especially among the educated class of both the countries. Over the years the news, the headlines, the events, the treatment meted at by media; are all the same.

\section{Multimodal Critical Discourse Analysis}

a. Semantic Macro-Proposition: It is the overall and general meaning of the text. Words and phrases are definitely useful in understanding the meaning of the text but at the same time each word can also have a secondary macro-proposition that helps in understanding the ideology of the text. Secondary macro proposition leads to passivization. 
b. Global superstructures: It is the analysis of news text in terms of structure; providing information about the main story and its implications. Structural features are important because audience recognize them as such and use them, often unconsciously, to facilitate their understanding the news text. Again we can observe ideology and power relations at play in the background.

c. Local Meaning: It gives a clear and underlying meaning of each word or phrase etc. at local level of news discourse. The inter-relation between meaning and interpretations becomes evident at local level such as: words, phrases, clauses and sentences.

d. 'Subtle' Formal Structures: Here the focus is on linguistic features and markers that range from word order to the syntactic structures.

\section{e. 'Non-Linguistic' Elements}

Images with the events will be analyzed based on visual design, sound, action/gestures, space, mathematical symbolism and typography. This analysis will be further divided into:

\section{i. Rendition as Presentation}

Presentation of the main character can be implicit or explicit; it can predict the role of the actor. This presentation can be repetitive or innovative. Repetitive factors mainly focus on the presentation of an image based on the cultural or stereotypical aspect, thus bringing out the ideology. Innovative refers to the metaphorical-type of presentation.

\section{ii. Rendition as Intensification}

While interpreting the images, this aspect focuses on the emotional aspect. It is also rooted in the ideology, as it plays on the perception of the reader to build a distance with the image. The colours, line, distance and angle from the main actor - all intensify or de-intensify the image.

\section{iii. Rendition as Identification}

It alludes to the cultural and historical background of the reader focusing on the sense of closeness or alienation from the image. In-group and out-group notions also come into play here. Close-distance or long-distance shot aids in identification with the actors involved.

\section{iv. Rendition as Implementation}

Repetitive presentation and identification helps and (to some extent) condition the readers to make implications relating to their history and culture which consequently helps in implementing a certain ideology.

For the sake of convenience, the study is divided into two broad categories, namely: Political, and Social; to trace the elements of duality, play of power relations and the semblance of ideology in the Headlines.

\begin{tabular}{|l|l|l|l|}
\hline Year & Newspaper & \multicolumn{2}{|l|}{} \\
\cline { 3 - 4 } & & Political/Military & Social \\
\hline
\end{tabular}




\begin{tabular}{|l|l|l|l|}
\hline 2015 & $\begin{array}{l}\text { The Dawn } \\
\text { The News } \\
\text { The Times of } \\
\text { India } \\
\text { The Hindu }\end{array}$ & $\begin{array}{l}\text { August 31-September 7 } \\
\text { Cross-border ceasefire } \\
\text { violations } \\
\text { August 22, 23 } \\
\text { NSA talks cancelled }\end{array}$ & $\begin{array}{l}\text { August 13-September 2 } \\
\text { Phantom movie reactions }\end{array}$ \\
\hline
\end{tabular}

\section{RESULTS AND DISCUSSION}

\section{First Event of Year 2015 - August 31-September 7 (Cross-border ceasefire violations)}

\section{a. Semantic Macro-Proposition}

Semantic Macro Proposition represent the overall, general meaning of the headline. Each word, phrase or item collectively adds up to the comprehensive meaning of the headline. It leads to secondary macro proposition, which plays a secondary but vital role in the interpretation of the headline, thus, exposing the political/editorial ideology of the text.

The first significant event in 2015 was cross border ceasefire violations and both sides blamed each other. The media hype was a bit escalated and Indian forces came up with some evidence which were denied by Pakistan. Macro proposition at semantic level showed the headlines about the arrest of a Pakistani boy on a spy mission in Indian held Kashmir. The foreign office asked for the proofs. This arrest was the first episode in the series of various events concerning cross border violations. This so-called spy disappeared from the scene within few weeks. Second episode was various incidents of firing across the border which may and may not have resulted in the killing of soldiers and civilians. Third episode was the meeting among government and military officials to discuss security situations, which was followed by strong statements from the chiefs of Army Staff of both sides. Fourth episode was the taking up of this case with United Nations. All these episodes lead to the security talks preparations at ministerial level.

Secondary macro proposition shows a very tenacious ideology lurking under the apparent surface. These chains of events are reflective of the fact the, LoC skirmishes are part of the routine. The strong statements by the military heads only confirm that these disputes are un-resolvable. As opposed to previous year's reporting, this year Pakistani newspapers also focused on the specific places and facts and figures to lend authority to their headlines.

The 'wh-questions' formula for the headline can be seen in carefully designed details.

Who - Pakistan and Indian military

Pakistan and Indian military and government officials

Victims (soldiers and civilians)

United Nations

What - cross border cease fire violations

Where - working border between India and Pakistan (LoC)

When - spanned over the period of almost three months

Indian newspapers adopted the exactly same pattern. The first episode was the arrest of an alleged Pakistani spy and the case prepared against him. His statements in calling Pakistan as a 'terror-sponsor' country are highlighted. Then the events and places that were affected by cross border shelling; are mentioned. The only difference is, where Pakistan took up the case with the 
United Nations, Indian media did not give this any significance. It can have dual meanings. Firstly, the Indian media only operates on the ideology which dictates to defame every intention of Pakistan and secondly, India in its high-handed approach does not much care about the role of United Nations at the working boundary.

\section{b. Global Superstructures}

Global superstructures inform about the main story and its implications, in terms of the structure of the headline. Clear structure, whether active or passive helps the readers to steer a concise interpretation and comprehension, which touches upon the discursive nature of readers. That is why carefully constructed structures offer a field for the propagation of certain ideology.

The ideology that is propagated in the series of headlines is obvious to any rational mind. One side is portraying that their actions are right and justified. The other side is also justifying their acts by providing proofs which simply got dwindle within few weeks. Global super-structure and macro proposition cleverly bring these ideologies to the light.

\section{c. Local Meaning}

Local meaning of the headline has its implications rooted at the local or cultural level. It refers to the explicit or implicit meanings, allusions, vagueness and even omission of words and phrases.

Historically, each and every word has a deep-seated local meaning and its implications. India alleges arrest of a Pakistani spy. The word 'alleges' is tactically placed, to show distrust in Indian allegation and to nullify their claim. Rather foreign office asks them to give the evidence. The Indian media went into frenzy of statements and proofs to justify their claim about Naved as a terrorist from across the border. All these claims were denied by Pakistan foreign office swiftly, saying that Naved is not even a registered citizen of the country. After this war of words, quite an extensive space is given to the events of shelling and firing on both sides of border. These occurrences were primed through many stimulating phrases. These include; 'gun battles, Indian firing, security situation, threat to international peace, shell border villages, hurling unfounded allegations, border violations, Naved arrow to pin Pakistan, Naved foxes interrogators, blows Pak denials sky-high, pounds border areas, infiltration bid and long and short war'. All these words are not just lexical features and styles. They are loaded with interpretations, implications and allusions which can profoundly affect the peaceful future of the two countries.

\section{d. 'Subtle' Formal Structures}

Formal structure mostly refers to the linguistic markers of the headline, including the word order, lexical style, coherence, speech acts or syntactic structures.

The syntactic structures and lexical styles reveal multi-layered meanings. Strong verbs and emotive vocabulary is used when writing about the cross border incidents. Combination of strong verbs and adjectives sends across a very direct message in a statement by foreign office that says that India should refrain from hurling unfounded allegations. The word allegation has cultural allusion, which might be referring to the fact that India has always indulged in constructing allegations without solid proofs. The war of words can be directly observed in the exchange of statements by Army chiefs. Indian chief said that they are 'ready for short, swift wars', which were directly answered by Pakistani chief in a statement saying, 'cold or hot start', they are ready for 
anything. On the surface, this is nothing but engagement in verbal war but indirectly each side gives message to each other to tread these grounds carefully.

The coverage given by Indian media to Naved's episode is an excellent example of how one can build a case in media with interviews, images and far-fetched evidence and witnesses. The alleged spy is termed as hardened jihadi - that means he got such an extensive training that he was not easy to break. The people arrested as his aid and his father's statements are all used to give the confirmation to the fact that he is a genuine case. Even all these claims raise suspicions. How can any country give such an extensive coverage in media to an arrested spy with a terrorist mission?

\section{f. Non Linguistic Elements}

In the current study, non-linguistic features are the images which complement each story.

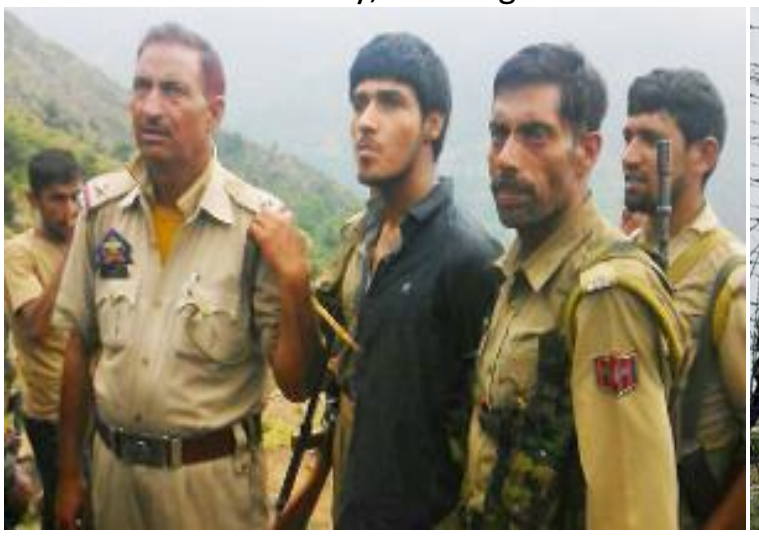

Figure 1: Arrested spy

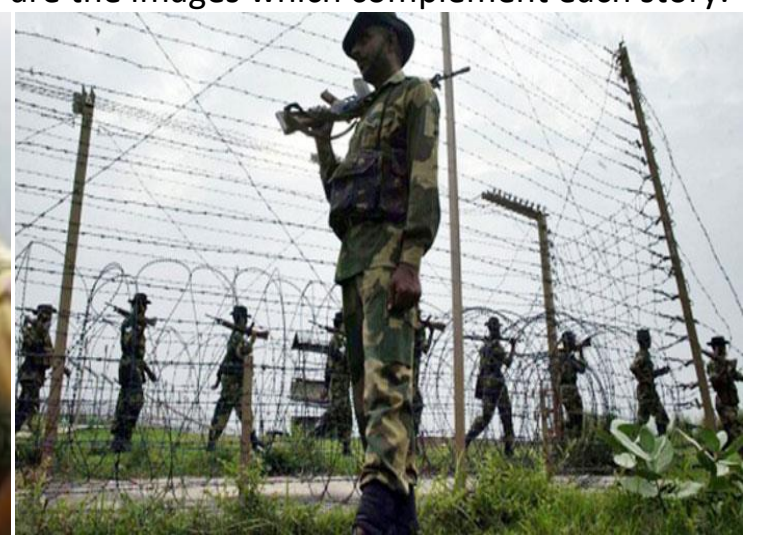

Figure 2: LoC between Pakistan and India

Rendition as Presentation: The presentation of alleged Pakistani spy in figure 1 reveals ideology. There is repetitiveness with innovativeness, showing Pakistanis as terrorists. The innovation comes into play when a reader focuses on the presence of police who are not specialized forces or members of any agencies, which are normally seen in cases of such arrests. Figure 2, explicitly presents the situation at LoC between India and Pakistan. It is repetitive of the fact that both nations have strained relations. The innovative element is the focus on the barbed wires and not on the soldier.

Rendition as Intensification: Figure 1, shows the main actor from an above-line, focusing on his behavior and intensifying the ideology that Pakistan supports terrorism. In figure 2, there is no distance from the main element and the image is presented in natural lights. It implies that the LoC is that part between the countries which serves to intensify the emotions on both sides of the border. The soldiers are the central figure, but also showing that they are just the tools in this scheme.

Rendition as Identification: Repetitiveness of the same actors in different shapes makes them easy to identify by the readers. The closeness of the symbol of barbed wire can be immediately identified by the readers.

Rendition as Implementation: Symbol of barbed wire and the alleged spy with police can have many historical implementations. According to the newspapers ideologies, the focus will remain on the conflict.

\section{Second Event of Year 2015 - August 22, 23 (NSA talks cancelled)}

\section{a. Semantic Macro-Proposition}

Every year, both countries try to indulge in such diplomatic activities which could lead to peace talks. This year the preparation for talks and their agenda was the focus in the media. But unfortunately the NSA talks were cancelled owing to the air of mistrust and the clauses of agenda. 
Semantic macro proposition clearly and straightforwardly present the views of the foreign minister and office of Pakistan. Sartaj Aziz, foreign minister of Pakistan, presented the agenda which included the Kashmir issue. But India was seen to change their stance over the agenda, many times. Secondary macro proposition brings out the political ideology of the editors, which is deeply rooted in the fact that all the conflicts between Pakistan and India start and end with Kashmir issue, then how was it possible to start 'peace' talks without addressing the core issue. Indian foreign office also stressed on holding the peace talks. But they presented their own terms and conditions which were not accepted by Pakistani officials. On top of it, cross border violations added fuel to the fire.

The headlines give the typical 'wh-question' information to the readers at the first glance.

Who - Indian and Pakistan Ministers

What - NSA Peace Talks

Where - in India

When - August

In their calm approach Pakistani media was seen to focus on the peace talks by addressing all the core issues whereas, Indian media is seen to chant the same old tune. Secondary macro proposition shows that Indian newspapers did focus on the agenda of terrorism only but they highlighted the wails of the ministers who blamed Pakistan for insisting on the discussion of Kashmir issue, as they believed, that Pakistan is not sincere in efforts to make deals to curb terrorism in the region. One political ideology that becomes clear is that in 68 years of independence, Pakistan has shown interest in peace talks, focusing on all the core issues and Kashmir is the foremost core issue. On the other hand, India is seen to ignore Kashmir issue and blame their neighbor for not addressing other issues.

\section{b. Global Super-Structures}

Global superstructures of the headlines draw attention to the same ideology of both sides, yet again.

\section{c. Local Meaning}

Local meanings of all words have both explicit and implicit implications. The direct statements by the ministers reflect on the diplomatic efforts carried out on both sides. India's pre conditions are termed as worrisome meddling by Sartaj Aziz. The exchange of the conditions resulted in uncertainty over the talks. Ultimately, NSA dialogue was cancelled over India's insistence in excluding Kashmir from the agenda.

The accusing tone of TOI headline can be seen in the word 'even', when it says, Pakistan's even got a dossier. This implicates a mocking tone towards Pakistan. The officials in India kept on insisting to discuss only terrorism and not Kashmir in the talks. 'Pak took K-refuge over fear of being exposed by India on terror'. All such statements have multi-layered interpretations. At one level, India's traditional insistence of not discussing Kashmir at any level is exposed. At another level, it shows Indian's attitude of blindly blaming Pakistan for terrorism in their country and not accepting Kashmir as the core issue to many other complicated conflicts. Congress party issued a direct question saying, why this Kashmir fixation? This question can be debated at many levels. One simple retort can be - why not?

\section{d. 'Subtle' Formal Structures}

All the linguistic markers points at the calm and calculated responses recorded in 'The Dawn and News'. Combination of verbs and adjectives has created the atmosphere of concern over Indian 
behavior. Some such phrasal combination include: 'New Delhi's meddling worrisome, uncertainty hang over Pak-India talks after spat, only option, Indian conditions, if Kashmir is on the table'. All these phrases create vibrant headlines to convey Pakistani newspapers ideology.

Keeping in line with the tradition of putting all the blame on Pakistan, Indian newspapers have again resort to the aggressive and emotional vocabulary to put all the blame on Pakistan for the cancellation of NSA talks. 'Pakistan even got a dossier, Pakistan cries off pre-midnight headlines, plays Kashmir card, wriggle out of talks, ' $\mathrm{K}$ '-refuge, fears of being exposed, deviated from talks agenda, wrangling over Hurriyat, Kashmir fixation, talks are off' - these are all the amazing combinations of lexical features which clearly and explicitly brings out the tone and agenda in Indian newspapers.

\section{Third Event in the Year 2015 - August 13-September 2 (Phantom movie reactions)}

a. Semantic Macro-Proposition

As discussed earlier, Pakistan and Indian media are actively involved in verbal duels when it comes to political issues or military issues or sports events. Such an attitude can also be seen in reactions to some movies, especially when they are based against each others' political ideology. One such movie was Bollywood movie 'Phantom'. They movie raised many controversies even months before its release. The movie was based on a book written in the context of 2008 Mumbai attacks. Allegedly the mastermind of those attacks, Hafiz Saeed was in Pakistan. The movie and its makers received a severe reaction from him and it was banned from screening in Pakistan.

Semantic macro proposition shows a bunch of headlines about the criticism, reaction and banning of the film in Pakistan. But close examination reveals a very intense ideology at play. One question about the future of the film is sufficient enough to put the credibility of the movie for the movie-goers. 'How will it fare?' This question might have resulted in arousing curiosity among the fans; the bans might have incited the people about the content of the movie. So, varied implications can be observed.

The Indian newspapers focused more on the statements of shock from the cast and makers of the movie. They claim that the facts in the movie are allusions to previous RAW operations. Even this statement becomes suspicious as out rightly RAW missions are mentioned and historically Pakistan has always claimed that RAW, has a hand in their domestic turbulent state of affairs.

The obvious 'whats and whys' are answered in almost all the headlines as follows:

Who - makers of movie/Hafiz Saeed and MSF

What - ban on 'Phantom'

Where - Pakistan and India

When - before the release of movie

\section{b. Global Super Structures}

Globally structure of headlines is undoubtedly straightforward. There is not much of a conflict in any of the headlines but the statements from both sides clearly indite that the film makers and real life actors of the event are wary of each other.

\section{c. Local 'Meanings'}


The participants of the event are the movie makers and the real life actors who demanded a ban on the movie in Pakistan. It should be noted that it is not just Hafiz Saeed who opposes the screening of 'Phantom'; its Medical charity MSF who also took legal action against the movie. The media on Pakistan side mostly focused on the concern of the participants in Pakistan. Since it is about Mumbai attacks, the question: 'How will it fare?'; makes sense. Historically Pakistan has a huge fan following for Indian film industry. But when it comes to criticizing and discussing the topics that undermine Pakistan's sovereignty then that traditional patriotic ideology comes to the surface. It became obvious when the film was ban in Pakistan.

The main actor of the movie gave direct statements over the ban, implying the mistrust and shock he has for Pakistani system. Very realistically 'The Hindu', in a headlines reviewed after the release of the movie that concept was thrilling but the treatment of the movie was substandard. It shows the ideology of the masses that if there is anything against Pakistan, it is thrilling.

\section{d. 'Subtle' Formal Structures}

Simple, concrete words are used to show the anger of certain factors against the movie. One interesting play on words can be seen in a headline which says that 'the actor who played Hafiz Saeed in the movie goes underground'. This placement of the word 'underground' provides an interesting twist.

'The Hindu' calls the movie as having thrilling concept, soppy treatment. This combination of words and use of rhetorical figures helps in bringing out the newspapers ideology. There is the impression of a general unhappiness over not cashing in, on a thrilling concept, which is of course labeling Pakistan as terrorist-supporter.

\section{e. 'Non-Linguistic' Elements}

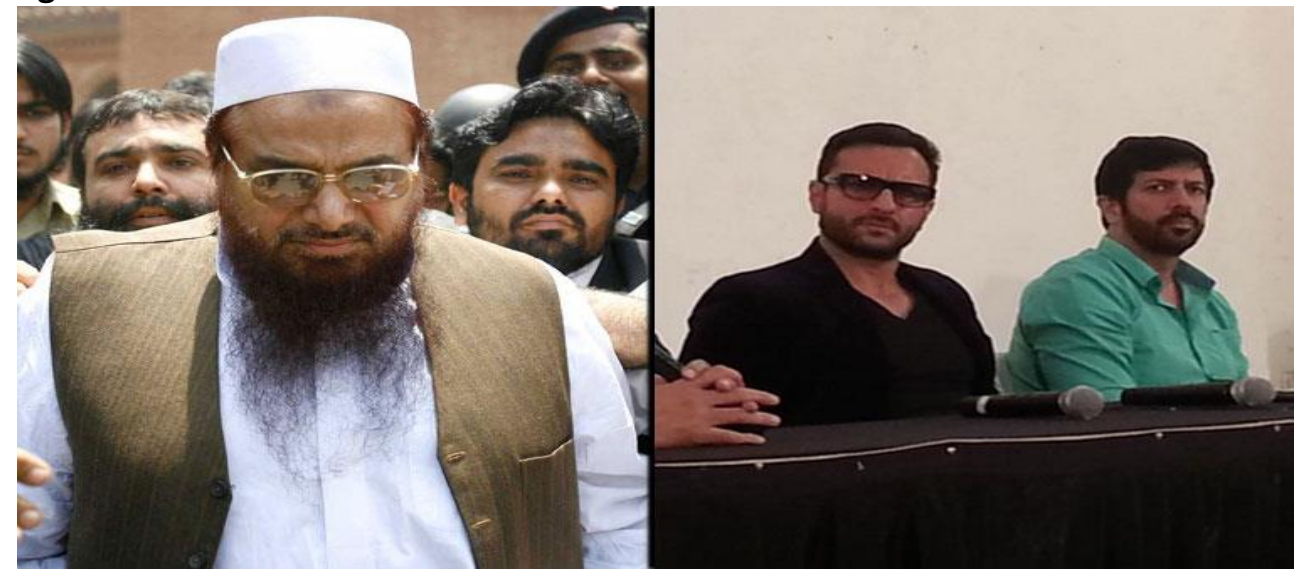

Figure 3: 'Phantom' movie makers and Hafiz Saeed

Rendition as Presentation: The two main actors in the process of banning a Bollywood movie are presented in the same frame. Both the actors are shown from front and close distance, which makes it easier to see their expressions.

Rendition as Intensification: The closeness of actors, straight lines in the images, intensifies the expressions on their faces. 
Rendition as Identification: Witnessing the verbal war about the movie, from both sides and the straight shot of the image makes these actors easily identifiable by the readers. One of them brings out the symbol of religious bigotry and the other tries to show face of tolerance amid conflicts at various levels.

Rendition as Implementation: The symbols in these can be taken as the grim expressions on the faces of actors in both the frames, implementing the future continuation of such conflicts.

\section{Conclusion}

The professional responsibility of a journalist and a news agency lies in the ideal and factual presentation of the news. High ethics demand that newspapers adhere to the high standards of honesty and impartiality. But the ground reality shows different picture. It's that side of the picture which reflect loyalties to particular ideologies be at national or international level. The newspapers structure their headlines to comply and practice their ideologies that can have roots to the national ideologies. The overall pattern observed in the present comparative study highly focused on the presentation of 'positive in-group image' and 'negative out-group image'. The negative elements of the out-group can be conveniently presented in the clever play on words, through the use of rhetorical speech and concrete images. Generalizations in the headlines provide a reader to fall back on his discursive mind and create specific implications about a certain event.

Media content does support the interest of those who 'run' the society. It is but natural for the journalists to adhere to certain ideologies and capitalist owners conveniently work on these ideologies to serve their purposes. These journalists mostly believe in middle-of-the-road approach as this appeals to the majority and keeps the masses complacent passive and in some cases, even dumbed down. So, in this way media discourse sets an agenda to decide which events need to be discussed by society. The dominant media content is presented as normal and any progressive or even different views are taken as unacceptable, from an out-group.

This study was mainly concerned with the ideologies presented by the four selected newspapers of Pakistan and India, to the masses. At times, it was observed that ideological implications were intentional and at other times, they were presented as a natural consequence of certain events. MCDA proved very beneficial in understanding the hidden ideological meanings lurking in the apparent straightforward rhetorical headlines in the four newspapers. The 3 categories showed that Pakistani and Indian newspapers give very subtle space and coverage to all these categories. Media on both sides have field days when it comes to the presentation of political and military events. Sporting events are accentuated through far-flung rhetorical figures and social events adopt the tone of sobriety. Such representations provide a spring board to create pre suppositions, arguments, macro-propositions and implications in the minds of the readers. The political events are mostly supported through the use of speech as headlines and sporting events have more of pointers as headlines. Social issues and events have seen headlines which mostly bring the masses together by presenting almost a neutral ideology.

Synchronicity, that is the repetition of words and phrases in the same issue; and diachronicity, that is repetition of words and phrases over a period of time; can be clearly ascertained in the headlines. National issues are almost repeated with the same robustness and vocabulary, hence, influencing the collective ideology of masses. Such collective ideology of social representation and 
nationalism can also be seen in events which affect the nation's psyche as a whole. These events produced headlines which affected the masses to highlight their nationalistic ideology.

Strong cultural and historical allusions were brought to the surface by doing the analysis of the headlines at semantic macro-proposition and global super-structures level. Local meanings further revealed that cultural aspects are anchored in their interpretations. The events reflected on the fact that both the countries have almost same cultural and historical backgrounds, therefore, the implications of most of the events was same for both sides. The only observed difference could be seen in the ideology was that my-version-of-the-story-is-the-only-version. As a consequence, public on both sides were given the same story with the respective ideology of their country, focusing on the in-group and out-group concept. The priming and agenda setting effect can be seen here to shape public opinion.

Such ideologies, which are based on cognitive and social systems, have important functions to portray, that is, to maintain the national ideological control over the cognition of masses, thus creating a control which remains under the control of a bigger group. What we have seen in this study is; Indian media explicate a large social group with a more decisive control on the power relations between and among the two countries and the two nations. This larger group, that is; India, heavily influence the headlines rhetoric to present a lesser image of a neighboring country, thus maintaining a discursive control on the readers. The second actor in this power relation is Pakistani media, which is seen to employ such rhetoric which can be interpreted as that of 'acceptance', 'resignation' and a 'toned-down approach'. Consequently, Indian ideology can be seen to have a strong influence on public opinion. Pakistani ideology is also seen as a strong factor for the public. But India seems to exert a more powerful role in this power relation. So, these headlines can be seen to create social interest among the readers to establish their respective ideology.

MCDA not only focuses on the textual features of a discourse, it also draws attention to the non-linguistic features. This study analyzed the news-images, as non-linguistic features in this analysis. The basic approach of visual analysis, that is, sign-signifier-signified was adopted. But it was conjoined with some other basic elements which focus more on the multi-modality of the discourse. Compelling images reflect an ideology that induces intense emotions and trigger automatic responses that are primarily set up to determine the ideology. Since these images reflect on the cognition of the readers, therefore, some of the images have a survival value that is difficult to ignore and serves a more practical usage by being stored in memory rather than stimuli that do not elicit any emotion. So the media discourse frames the images in a way that they are retained in memory to elicit emotions. The premise is that highly emotionally arousing media messages would be remembered more than less-emotion arousing media messages. The observed pattern tend to reflect the same ideological features, showing that the newspapers are working on a certain agenda, which in this case is to establish power relation. This brings us to the next point of discussion. Why these newspapers gave importance to certain events and totally ignored the others?

All the four newspapers are the leading newspapers of the two countries, to maintain their popularity and monopoly among the masses, they have to create newsworthiness. Timelessness and conflict are the major factor to determine newsworthiness. Most of the events concerning the masses and readers are timeless and conflicting in nature. The best examples are the cross border ceasefire violation, resulting in failed peace talks, almost always; Kashmir and terrorism at the back 
hand of every conflict and the timelessness that can be seen 'before, during and after events' of sports events.

The study provided an insight into mechanism of headlines in the newspapers. Through the comparison of Pakistani and Indian leading English newspapers, it is expounded that at semantic levels, the headlines are propagating the ideologies and shaping public opinion, based on their news agency or the government. Not only ideology, these headlines are responsible to establish and strengthen power relation among the main actors in this chain. Even the newsworthiness of certain events is created to underline the ideological background among readers.

How the newspapers achieved this task of constructing the ideologies? It has been done through the constant drilling in of the same tone and tenor of the coverage of some specific events and they have successfully managed to hammer in the ideals of nationalism and rhetoric of hatred towards each other by mirroring the selective reality. Some special instances could be observed by both sides when especially it comes to the coverage of political, terrorist or LoC related events. The style adheres to 'blame-it-all' on the other party. Some headlines on both sides even attributed vested motives and interests to the government.

During cross-border cease fire violations, one example of ideology can be seen in the following headlines:

The Dawn: "India should provide proof of any Pakistani involved in terrorism: FO"

The Hindu: "Show us solid proof, Pakistan tells India"

Pakistani media resort to the official statements from the government officials, asking for the proofs. This shows that they play safe game and quote authorities to reflect on their credibility; thus, creating a mass acceptance about their reporting. At the same time, The Hindu, plays on the emotional side of readers with an overbearing tone, when they say that Pakistani media "tells" them to show proofs. The verb "tell" encompasses many emotions even laden with sarcasm. Where Pakistani paper sets an agenda of adhering to the middle-of-the-road approach, the Indian media adheres to outright sarcasm. It also shows that news norms also becomes the reason for agenda setting.

The strong words are used as weapon by Indian media, showing their control over these channels. The strong verbs like "snap, sparks, terror, cries off, pounds, to pin" are used to establish their stance. Whereas, Pakistani media sticks to a toned down approach by sticking to the facts. Semantic and visual analysis revealed the same ideology in operation, showing the diversity in media communication.

\section{References}

AFP. Published August 10, 2015. Indian soldier, two militants killed in Kashmir gunbattles. Retrieved from: http://www.dawn.com/news/1199503/indian-soldier-two-militants-killed-in-kashmirgunbattles-police

Al Ali, G. (2011). Hero or terrorist? A Comparative analysis of Arabic and western media depictions of the execution of Saddam. Discourse \& Communication: Sage

Andrew, B. C. (2007). Media-generated Shortcuts: Do Newspapers Headlines Present another Roadblock for low Information Rationality? Press/Politics 12 (2): 24-43: Sage Publications. 
Basu, M., Published: August 14, 2015. Phantom's factional parts inspired from previous RAW operations. Retrieved from:

http://timesofindia.indiatimes.com/entertainment/hindi/bollywood/news/Phantomsfactional-parts-inspired-from-previous-RAW-operations/articleshow/48467871.cms

Baqir, S., Updated September 7, 2015. Cold or hot start, army ready for anything. Retrieved from: http://www.dawn.com/news/1205403/cold-or-hot-start-army-ready-for-anything-coas

Baqir, S., Updated August 23, 2015. NSAs' talks cancelled over Indian conditions. Retrieved from: http://www.dawn.com/news/1202269/nsas-talks-cancelled-over-indian-conditions

Blommaert, J., \& Bulcaen, C. (2000). Critical discourse analysis. Annual Review of Anthropology, 29, 447-466.

Cooky, C., et al (2013). "What Makes a Woman a Woman?" versus "Our First Lady of Sport": A Comparative Analysis of the United States and the South African Media Coverage of Caster Semenya. Journal of Sports and Social Issues. Sage Publications: 37(1) 31-56)

Correspondent. Published: February 16, 2015. World Cup jinx continues for Pakistan. Retrieved from: http://www.thenews.com.pk/Todays-News-10-301937-World-Cup-jinx-continues-for-Pakistanas-India-win-again

Correspondent. Published August 21, 2015. Court bans Indian film display. Retrieved from: http://www.thenews.com.pk/Todays-News-5-335329-Court-bans-Indian-film-display

Correspondent. Published September 6, 2015. Pakistan takes up Indian firing at LoC, working boundary with UNSC, Retrieved from: http://www.dawn.com/news/1205257/pakistan-takesup-indian-firing-at-loc-working-boundary-with-unsc

Correspondent. Published: September 8, 2015. Indian troops resort to unprovoked firing in Kailer Sector. Retrieved from: http://www.thenews.com.pk/Todays-News-13-39522-Indian-troopsresort-to-unprovoked-firing-in-Kailer-Sector

Curran, J. (2002) Media and Power. London and New York: Routlegde.

Dearing, J. W. \& Rogers, E. M., (1996). Agenda-Setting, Sage.

Djonov Emilia, Zhao Sumin, eds (2014), Critical Multimodal Studies of Popular Discourse, London-New York (NY), Routledge

Downing, J., Mohammadi A. and Sreberny-Mohammadi A.S (1995) Questioning the Media: A Critical Introduction. London Thousand Oaks, New Delhi: Sage Publications.

Entertainment Desk. Published July 28, 2015. Saif Ali Khan's film Phantom. Retrieved from: HTTP://WWW.DAWN.COM/NEWS/1196889

Fairclough, N. (2001). Critical discourse analysis as a method in social scientific research. In R. Wodak, \& M. Meyer (Eds.), Methods of Critical Discourse Analysis (pp. 121-138). London: Sage Publications Ltd.

Fairclough, N. and Wodak, R. (1997) 'Critical Discourse Analysis'. In T. van Dijk Discourse as Social Interaction. London Thousand Oaks, New Delhi and Singapore: Sage Publications.

Fang, Y. (2001). Reporting the Same Events? A Critical Analysis of Chinese Print News Media Texts. Discourse \& Society: Sage Publications. Vol 12 (5)

Foucault, M. (1993/1972). The Archaeology of Knowledge and The Discourse on Language. (A. M. Sheridan Smith, Trans.) Barnes \& Noble Inc

Hall, S. (1996). Cultural studies and its theoretical legacies. In D. Morley, \& K.-H. Chen (Eds.), Stuart Hall: Critical Dialogues in Cultural Studies (pp. 262-275). New York: Routledge.

Kress, G. and Van Leeuwen, T. (2001) Multimodal Discourse: The Modes and Media of Contemporary Communication Discourse. London: Arnold. 
Leeuwen, T. van (2013), "Critical Analysis of Multimodal Discourse”, in C.A. Chapelle (ed.), Encyclopedia of Applied Linguistics, Oxford, Wiley-Blackwell, 5; (11/2014).

Lull, J. (2003). Hegemony. In G. Dines, \& J. M. Humez (Eds.), Gender, Race and Class in Media: A TextReader (pp. 61-66). Thousand Oaks: Sage.

Machin, D. and Mayer, A. (2012), How to Critical Discourse Analysis. A Multimodal Introduction. London: Sage

McCombs, M. (2003)The Agenda Setting Role of Mass Communication: Mass Media and Public Opinion, Egyptian Journal of Public Opinion Research 1 (2) 1-3 \& 1 (3) 83-84

Meyer, M. (2001). Between theory, method, and politics: Positioning of the approaches to CDA. In R. Wodak, \& M. Meyer (Eds.), Methods of Critical Discourse Analysis (pp. 14-31). London: Sage Publications, Ltd.

Scollon, R., \& Levine, P. (2004). Multimodal discourse analysis as the confluence of discourse and technology. In P. Levine, \& R. Scollon (Eds.), Discourse and Technology: Multimodal Discourse Analysis, Volume 2002 (pp. 1-6). Washington, D.C.: Georgetown University Press.

Taiwo, R. (2007). 'Language, Ideology and Power Relations in Nigerian newspaper Headlines', Nebula: A Journal of Multidisciplanary Scholarship: Atria, India

The Newspaper's Correspondent. Published September 5, 2015. Indian Troops shell border villages. Retrieved from: http://www.dawn.com/news/1205040/indian-troops-shell-border-villages

Van Dijk, T.A. (1988). News Analysis. Hillsdale: Erlbaum.

Van Dijk, T.A. (1995a). Discourse analysis as ideology analysis. In Wenden, A. and Schaffner, C. (eds) Language and Peace (in press).

Van Dijk, T.A. (1995b). Discourse semantics and ideology. Discourse \& Society 6: 2. 243-289.

Van Oostendorp, H. and Zwaan, R.A. (eds) (1994). Ideology a multidisciplinary approach. Sage Publications

Wodak, R. (2001). What CDA is about - a summary of its history, important concepts and its developments. In M. Meyer, \& R. Wodak (Eds.), Methods of Critical Discourse Analysis (pp. 113). London: Sage Publications, Ltd.

Zhang, M. (2012). Stance and Mediation in Transediting News Headlines as Paratexts. Perspectives: Studies in Translatology, 21:3, 396-411, DOI: 10.1080/0907676x.2012.691101 